\title{
GAYA KEPEMIMPINAN DAN PRAKTEK BISNIS SERTA PENGARUHNYA TERHADAP KINERJA UKM DI PROPINSI ACEH
}

JULLIMURSYIDA

Fakultas Ekonomi dan Bisnis, Universitas Malikussaleh, Lhokseumawe

This study was conducted to determine the effect of leadership style and business practices that run on the performance of small and medium enterprises. The data for this study will be obtained by distributing questionnaires. The questionnaire had been developed distributed to employees of SMEs. In order to achieve the research objectives and addressing existing research, the data that has been collected will be analyzed using multiple regression, with the help of SPSS (Statistic Package for Social Science). The results of this study indicate that leadership style has a positive influence on the performance of SMEs, and business practices that run also has a positive effect on the performance of SMEs

Keywords: Leadership Styles, Business Practices, Performance, Small and Medium Enterprises (SMEs), The Intensity of Competition 


\section{LATAR BELAKANG}

Tidak dapat dipungkiri bahwa pertumbuhan penduduk akan menyebabkan pertambahan jumlah angkatan kerja. Jika pertambahan penduduk ini tidak diikuti oleh daya dukung ekonomi nasional, terutama sektor-sektor ekonomi yang seharusnya dapat diandalkan untuk menanggung beban tersebut, maka konsekwensinya akan menghadirkan permasalahan tenaga kerja yang rumit. Apalagi bila kondisi ini berlangsung didalam kurun waktu yang panjang, maka permasalahan menjadi semakin rumit dan kian sulit diatasi salah satu permasalahan penting yang akan dihadapi adalah pertumbuhan ekonomi.

Industri kecil dan industri rumah tangga menjadi andalan pemerintah baik ditingkat nasional maupun daerah untuk memacu pertumbuhan ekonomi. Geliat yang ada dan daya tahan industri kecil dan industri rumah tangga ini terbukti memberi kontribusi besar dalam memacu pertumbuhan ekonomi terutama dalam menyediakan lapangan kerja.

Untuk mengembangkan sektor industri di Provinsi Aceh diperlukan langkah-langkah/kebijakan strategis yang komprehensif dan dipahami oleh semua pihak. Berdasarkan data yang diperoleh diketahui bahwa kesempatan kerja yang mampu disediakan oleh sektor industri, seperti contoh pada industri kecil di Kabupaten Aceh Utara sangat berarti dan dipandang sangat perlu untuk dikembangkan, seperti disajikan pada Tabel 1.
Tabel 1 menunjukkan bahwa industri kecil sangat banyak yang mempunyai potensi untuk dikembangkan karena mampu menyerap tenaga kerja dan memberi kontribusi yang besar terhadap output daerah. Dari 1.301 industri kecil informal di atas saja telah mampu menyerap tenaga kerja mencapai 4.332 orang tenaga kerja, setidaknya jumlah ini ditambah dengan jumlah tenaga kerja yang ditampung pada industri kecil formal telah membantu lebih dari 43.838 orang pencari kerja yang terdaftar pada Dinas Tenaga Kerja Kabupaten Aceh Utara.

Untuk mengembangkan usaha kecil dan menengah di propinsi Aceh, diperlukan komitmen dan kerjasama semua pihak terutama pemerintah daerah dan juga lembaga keuangan. Sebagaimana diketahui bahwa banyak kendala yang dihadapi oleh usaha kecil dan menengah salah satunya adalah sulitnya untuk memasarkan produk-produk yang dihasilkan.

Oleh karena itu, peningkatan kinerja perusahaana dalah impian setiap pimpinan usaha kecildan menengah (UKM). Berbagai usaha akan ditempuh untuk mencapai impiantersebut mulai dari pemasaran, keuangan sampai memberikan pelayanan kepadakonsumen. Semua hal tersebut memerlukan keahlian pimpinan dalam mengelolasumber daya manusianya. Terdapat perbedaan kinerja dari UKM, dimana ada UKM yang dapat terus menjalankan usahanya di masa krisis dan narnun ada juga yang harus menutupusahanya.

Tabel 1

Data Industri Kecil Non Formal yang Berpotensi Untuk di Kembangkan

(Menurut Komoditi) Tahun 2006

\begin{tabular}{|c|c|c|c|c|}
\hline No & Output Industri & Unit Usaha & Tenaga Kerja & Nilai Produksi \\
\hline 1 & Pisang Sale & 11 & 33 & 130.875 .000 \\
\hline 2 & Furnitur dari Kayu & 41 & 141 & 4.549 .030 .000 \\
\hline 3 & Bengkel Motor & 27 & 36 & 312.975 .000 \\
\hline 4 & Pandai Besi & 32 & 94 & 1.399 .136 .000 \\
\hline 5 & Batu Bata & 125 & 638 & 18.060 .090 .000 \\
\hline 6 & Bordir & 192 & 806 & 7.705 .606 .000 \\
\hline 7 & Garam & 213 & 676 & 2.302 .478 .000 \\
\hline 8 & Konveksi & 256 & 831 & 4.966.819.000 \\
\hline 9 & Kue Kering & 83 & 233 & 1.567 .480 .000 \\
\hline 10 & Bengkel Sepeda & 55 & 102 & 781.137 .000 \\
\hline \multirow[t]{2}{*}{11} & Dan lain-lain & 266 & 742 & 6.648 .843 .000 \\
\hline & Total & 1.301 & 4.332 & 48.424.469.000 \\
\hline
\end{tabular}

Sumber: BPS Aceh Utara, 2007 
Hult, Snow Kandemir (2003) mengatakan bahwa kebanyakan penelitian tentang UKM fokus pada aspek keuangan sebagai faktor yang menyumbangkeberhasilan usahanya dibandingkan penelitian yang menekankan pemahamantentang proses pertunbuhan dan pencapaian keunggulan kompetitif yang berkelanjutan pada UKM.

Banyak penelitian yang dilakukan selama ini bertumpu pada usaha berskala besar dan ini menyebabkan kurangnya hasil-hasil penelitian yang membahas UKM, padahal resiko usaha yang dihadapi UKM semakin meningkat (Chiara dan Antonio, 2002). Di tahun 1983, lebih dari 31.000 usaha mengalami kegagalan diAmerika Serikat, angka ini merupaka rangking keempat terbesar dalam sejarahAmerika. Perkiraan kegagalan usaha yang terjadi Amerika adalah sebesar 10.000/tahunnya dan kebanyakannya adalah UKM (Dunn \& Bradstreet, 1987). Oleh karena itu perlu dilakukan penelitian lebih mendalam untuk memahamikenapa terjadi perbedaan kinerja di UKM, dimana sebagian UKM dapat mencapaikinerja yang sangat baik tapi sebagiannya lagi tidak bisa mencapai kinerja yang diharapkan.

Dari identifikasi masalah diatas, maka tujuan dalam penelitian ini adalah untuk menganalisis pengaruh antara gaya kepemimpinan dengan kinerja UKM dan untuk menganalisis pengaruh antara praktek bisnis dengan kinerja UKM di Propinsi Aceh.

\section{KAJIAN PUSTAKA}

\section{Usaha Kecil dan Menengah (UKM)}

Kewirausahaan memang sangat identik dengan usaha kecil. Tidak banyak buku yang membahas tentang pengertian tentang usaha kecil dan menengah karena belum ada batasan dan kriteria yang baku mengenai usaha kecil dan menengah. Wheelen dan Hunger (2002) berpendapat bahwa usaha kecil dioperasikan dan dimiliki secara independen, tidak dominan dalam daerahnya dan tidak menggunakan praktek-praktek inovatif. Tapi usaha yang bersifat kewirusahaan adalah usaha yang pada awalnya bertujuan untuk tumbuh dan menguntungkan serta dapat dikarakteristikkan dengan praktek-pratek inovasi strategis.

Pengertian usaha kecil di Indonesia masih san- gat beragam. Setidaknya ada lima instansi yang merumuskan usaha kecil dengan caranya masingmasing. Kelima instansi itu adalah Biro Pusat Statistik (BPS), Departemen Perindustrian, Bank Indonesia, Departemen Perdagangan serta Kamar Dagang dan Industri (Kadin). Pada kelima instansi itu, kecuali BPS, usaha kecil pada umumnya dirumuskan dengan menggunakan pendekatan finansial.

Biro Pusat Statistik (BPS) Indonesia manggambarkan bahwa perusahaan dengan jumlah tenaga kerja 1-4 orang digolongkan sebagai industri kerajinan dan rumah tangga, perusahaan dengan tenaga kerja 5 - 19 orang sebagai industri kecil, perusahaan dengan tenaga kerja 20 - 99 orang sebagai industri sedang atau menengah, dan perusahaan dengan tenaga kerja lebih dari 100 orang sebagai industri besar.

Berdasarkan pada kelima batasan tersebut dapat diketahui betapa sangat beragamnya pengertian usaha kecil yang kini berlaku di Indonesia. Hill (1990) mendefinisikani idustri kecil sebagai perusahaan dengan jumlah antara 5 sampai 49 karyawan. Pengertian industri kecil juga dapat dipandang dari segi jumlah produksi atau hasil penjualan (Hill, 1990) atau dari segi nilai tambah (Hill, 1990), tetapi ukuran perusahaan lebih sering dinyatakan dengan jumlah karyawan. Definisi usaha kecil menurut Suryana (2001) umumnya mencantumkan karakteristik perusahaan yang tergolong usaha kecil 1) biasanya bersifat bebas, tidak terikat dengan identitas bisnis lain, misalnya sebagai cabang, anak perusahaan, atau divisi dari perusahaan yang lebih besar, 2) biasanya sepenuhnya dikendalikan oleh pemiliknya yang biasanya adalah owner-manager yang memberikan konstribusi kepada hampir semua hal, tidak hanya terbatas pada modal kerja, 3) otoritas pengambilan keputusan dipegang penuh oleh pemilik usaha.

Terlepas dari keragaman pengertian itu, kiranya penting untuk diketahui adalah karakteristik atau ciri-ciri usaha kecil secara urnum. Berdasarkan studi-studi yang dilakukan Mitzer serta Musselman dan Hugehs (1994) dapat disimpulkan bahwa ciri-ciri umum usaha kecil dalam garis besarnya adalah sebagai berikut: 1). Kegiatan cenderung tidak formal dan jarang yang memiliki rencana usaha. 2). Struktur organisasi bersifat se- 
derhana. 3). Jumlah tenaga terbatas dengan pembagian kerja yang longgar. 4). Kebanyakan tidak melakukan pemisahan antara kekayaan pribadi dengan kekayaan perusahaan. 5). Sistem akuntansi kurang baik, bahkan kadang-kadang tidak memilikinya sama sekali. 6). Skala ekonomi terlalu kecil sehingga sukar menekan biaya. 7). Kemampuan pemasaran serta diversifikasi pasar cenderung terbatas. 8). Margin keuntungan sangat tipis.

\section{Gaya Kepemimpinan}

Gaya kepemimpinan adalah kemampuan dari pemimpin untuk mempengaruhi bawahannnya dalam rangka pencapaian tujuan organisasi (Armandi, Oppedisano \& Shemar, 2003). Cara ini mencerminkan sikap dan pandangan pemimpin terhadap orang yang dipimpinnya dan merupakan gambaran gaya kepemimpinannya. Fungsi kepemimpinan menurut Hill (1985) memiliki dua dimensi sebagai berikut: 1) Dimensi yang berkenaan dengan tingkat kemampuan mengarahkan(direction) dalam tindakan atau aktivitas pemimpin, yang terlihat pada tanggapan orang-orang yang dipimpinnya; 2). Dimensi yang berkenaan dengan tingkat dukungan (support) atau keterlibatan orang-orang yang dipimpin dalam melaksanakan tugas-tugas pokok kelompok atau organisasi, yang dijabarkan dan dimanifestasikan melalui keputusan-keputusan dan kebijaksanaan-kebijaksanaan pemimpin.

Berdasarkan kedua dimensi tersebut secara operasional dapat dibedakan lima fungsi pokok kepemimpinan, yaitu: 1). Fungsi instruktif; 2). Fungsi konsultatif; 3). Fungsi partisipasi; 4). Fungsi delegasi; 5). Fungsi pengendalian. Hartmant dan Harris (1992) membagi gaya kepemimpinan menjadi tiga yaitu: 1). The Autocratic Leader; 2). The Participative Leader; 3). The Free Rein Leader. Dimana keberhasilan suatu organisasi baik sebagai keseluruhan maupun berbagai kelompok dalam suatu organisasi tertentu, sangat tergantung pada mutu kepemimpinan yang terdapat dalam organisasi yang bersangkutan. Bahkan kiranya dapat dikatakan bahwa mutu kepemimpinan yang terdapat dalam suatu organisasi memainkan peranan yang sangat dominan dalam keberhasilan organisasi tersebut dalam menyelenggarakan berbagai kegiatannya terutama terlihat dalam kinerja para pegawainya.

\section{Praktek Bisnis}

Praktek bisnis akan memberikan pengetahuan dan pengertian tentang tujuan bisnis organisasi terutama bagaimana organisasi harus berjalan/ terlaksana dengan baik. Oleh karena itu dalam menjalankan bisnis di perlukan suatu sistem yang mengatur bagaimana seharusnya bisnis tersebut dijalankan sehingga dapat berjalan sesuai yang diharapkan.

Madu et al. (1996) melakukan penetitian mengenai pengaruh dimensi-dimensi kualitas terhadap kinerja organisasi. Dengan mengambil data dari 165 manajer di Mid-Atlantic USA yang sedang mengambil Pogram MBA, dimensi kualitas yang diukun adalah kepuasan pekerja, kepuasan pelanggan dan kualitas pelayanan pekerja. Variabel untuk kinerja organisasi adalah kinerja perusahaan jangka pendek, kinerja perusahaanjangka panjang, produktivias, kinerja biaya, profitabilitas, kemampuan bersaing pertumbuhan penjualan, pertumbuhan laba dan pangsa pasar. Hasil dari penelitian tersebut menunjukkan bahwa terdapat hubungan antara dimensi kualitas dengan kinerja organisasi. Sedangkan Hendrics dan Singhal (1997) meneliti pengaruh penerapan program TQM terhadap kinerja finansial dalam kegiatan operasi perusahaan. Hasil penelitian ini menunjukkan bahwa perusahaan yang telah mendaptkan quality awards, teryata mengalami kenaikan kinerja finansial.

\section{METODE PENELITIAN}

\section{Populasi dan Sampal}

Dalam penelitian ini menggunakan definisi usaha kecil dan menengah berdasarkan kriteria yang digunakan oleh Urata (2001) yang pengelompokkannya berdasarkan jumlah tenaga kerja yaitu usaha kecil yang memiliki jumlah tenaga kerja antara 10 - 50 pekerja. Sedangkan usaha menengah adalah usaha yang memiliki pekerja antara 51 - 250 orang. Selain itu UKM yang dipilih dalam penelitian ini adalah UKM yang telah beroperasi minimal tiga tahun dalam segala sektor.

\section{Pengukuran Variabel Penelitian}

Metode pengumpulan data dalam penelitian yang digunakan dalam penelitian ini adalah metode survei. Penelitian ini bersifat korelasional 
karena penelitian berusaha menyelidiki hubungan antara beberapa variabel penelitian bebas yaitu variabel gaya kepemimpinan, praktek bisnis dengan variabel terikat, yaitu kinerja UKM.

Pola hubungan antar variabel penelitian terlihat pada gambar berikut.

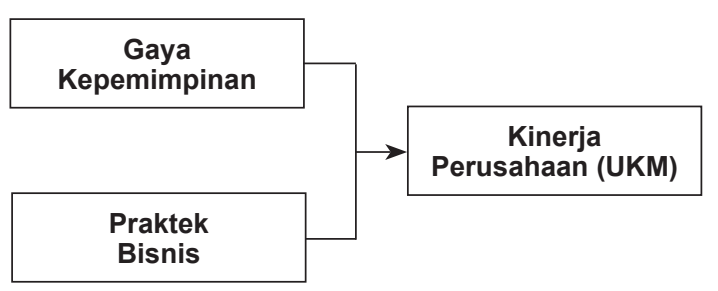

Gambar 1. Hubungan Antar Variabel Penelitian

Dari Hubungan antara variabel diatas, maka hipotesis yang dapat dirumuskan adalah:

H1. Gaya kepemimpinan berpengaruh positif dengan kinerja UKM

H2. Praktek bisnis berpengaruh positif dengan kinerja UKM

\section{Metode Analisis Data}

1. Uji Validitas dan Reliabilitas instrument, yaitu Uji validitas dilakukan untuk mengukur valid tidaknya suatu kuesioner (Ghozali, 2002). Salah satu cara untuk menguji validitas adalah dengan menghitung nilai korelasi. Uji reliabilitas. Suatu kuesioner dikatakan reliabel jika jawaban sesorang terhadap pertanyaan adalah konsisten dari waktu ke waktu yang dapat dibuktikan dari nilai Cronbach Alpha $>0.60$ (Nunnally, 1978)

2. Multiple Regression. Data akan dianalisis dengan menggunakan Multiple regression dengan peralatan SPSS versi 11.5. Penggunaan Multiple regression ini dikarenakan untuk melihat bagaimana hubungan antara gaya kepemimpinan dan praktek bisnis terhadap kinerja UKM, dimana dalam penelitian ini terdapat dua varibael bebas dan satu variable terikat yang semua variable tersebut diukur dengan skala interval.

\section{PEMBAHASAN}

\section{Response Rate}

Pengumpulan data dilakukan dengan cara penyebaran kuesioner dilakukan dengan mendatangi pemilik UKM dan menyerahkan kuesioner untuk diisi. Daerah yang dijadikan sebagai lokasi penelitian adalah Kota Lhokseumawe, Kabupaten Aceh Utara, Kabupaten Bireun, Kota Banda Aceh dan Kabupaten Aceh Besar. Dari hasil penyebaran kuesioner kepada 145 UKM, hanya 123 kuesioner yang didapatkan kembali, namun hanya 119 kuesioner yang dapat digunakan untuk analisis data. Sedangkan empat kuesioner lagi tidak bisa digunakan karena tidak lengkap dalam pengisiannya. Sebanyak 22 Kuesioner yang tidak kembali dikarenakan waktu responden dikunjungi oleh enumerator, pemiliknya tidak ada di tempat sehingga hanya dititipkan. Dan sewaktu dikunjungi kembali pemiliknya hanya menitipkan kembali kuesioner yang tidak lengkap diisi sehingga tidak dapat digunakan lebih lanjut untuk penelitian ini.

Tabel 2

Hasil Pengumpulan Data Primer

\begin{tabular}{lcc}
\hline \multicolumn{1}{c}{ Keterangan } & Jumlah & Persentase \\
\hline Jumlah kuesioner yang disebarkan & 145 & $100 \%$ \\
\hline Jumlah kuesioner yang kembali & 123 & $84,82 \%$ \\
\hline $\begin{array}{l}\text { Jumlah kuesioner yang tidak } \\
\text { kembali }\end{array}$ & 22 & $15,17 \%$ \\
\hline $\begin{array}{l}\text { Jumlah kuesioner yang gugur dan } \\
\text { tidak layak di analisis. }\end{array}$ & 4 & $1,37 \%$ \\
\hline $\begin{array}{l}\text { Jumlah kuesioner yang terjawab } \\
\text { lengkap dan layak dianalisis }\end{array}$ & 119 & $82,06 \%$ \\
\hline
\end{tabular}

\section{Karakteristik Responden}

Karakteristik responden menggambarkan identitas responden dari usia, jenis kelamin, dan lamanya responden bekerja yang diperoleh dari 119 responden seperti terlihat pada Tabel 3.

Tabel 3

Karakteristik Responden

\begin{tabular}{llcc}
\hline \multicolumn{1}{c}{ Item } & \multicolumn{1}{c}{ Kategori } & Freq. & Persentase \\
\hline Usia & 21 - 30 Tahun & 15 & 12,6 \\
& 31 - 40 Tahun & 95 & 79,8 \\
& 41 - 50 Tahun & 8 & 6,7 \\
& $>$ 50 Tahun & 1 & 0,8 \\
\hline \multirow{2}{*}{ Jenis Kelamin } & Laki-laki & 81 & 68,1 \\
& Wanita & 38 & 31,9 \\
\hline \multirow{2}{*}{ Status } & Belum menikah & 20 & 16,8 \\
Perkawinan & Menikah & 95 & 79,8 \\
& Janda & 4 & 3,4 \\
\hline Pendidikan & SMA & 79 & 66,4 \\
& D III & 20 & 16,8 \\
& SI & 20 & 16,8 \\
\hline
\end{tabular}


Berdasarkan Tabel 3 dapat diketahui dari 119 responden, bahwa usia responden didominasi oleh usia yang berkisar 31 - 40 tahun berjumlah 95 responden $(79,8 \%)$, dengan jenis kelamin dari responden didominasi oleh laki-laki (81 orang, $68,1 \%$ ). Untuk status perkawinan, 95 orang responden sudah menikah $(79,8 \%)$ dengan ratarata dari responden adalah lulusan SMA (79 responden, 66,4\%).

\section{Uji Validitas dan Uji Reliabilitas}

Penelitian ini menggunakan data primer yaitu berupa kuesioner atau daftar pertanyaan yang diberikan kepada responden sehingga perlu dilakukan pengujian atas instrumen pengumpulan data tersebut. Uji coba instrumen adalah sebagai berikut:

\section{Uji Validitas}

Uji ini dilakukan untuk mengukur sah atau tidaknya suatu kuisioner. Suatu kuisioner dikatakan valid jika pertanyaan pada kuisioner mampu untuk mengungkapkan sesuatu yang akan diukur oleh kuisioner tersebut. Uji validitas menunjukkan keadaan sebenarnya dan mengarah pada kesesuaian alat ukur (Neuman, 2000). Uji validitas dapat dilakukan dengan menggunakan uji Comfirmatory Factor Analysis (CFA) adalah untuk mengetahui apakah indikator betul-betul merupakan bagian dari indikator konstruk tersebut. Analisis faktor akan mengelompokkan masing-masing indikator kedalam beberapa faktor. Jika suatu indikator merupakan indikator konstruk maka dengan sendirinya akan mengelompok menjadi satu dengan faktor loading yang tinggi. Nilai rule of thumb yang digunakan untuk CFA harus $>0,40$ (Hair et al., 2006).

\section{Uji Reliabilitas}

Uji reliabilitas dilakukan untuk memastikan instrumen tersebut merupakan alat ukur yang akurat dan dapat dipercaya.Uji reliabilitas menunjukkan sejauh mana sesuatu hasil pengukuran terhadap aspek yang sama atau disebut juga dengan interval concistency reliability. Pada penelitian ini, uji reliabilitas alat ukur yang digunakan adalah dengan menggunakan cronbach alpha. Pedoman yang digunakan untuk mengetahui tingkat reliabilitas dilihat dari besarnya cronbach alpha yaitu nilai cronbach alpha $>$ 0,7 meskipun 0,6 masih dapat diterima (Hair et al., 2006).

Hasil pengujian validitas dan reliabilitas untuk setiap variabel dapat dilihat pada tabel 4 dibawah ini:

Berdasarkan tabel 4 di atas, dapat dijelaskan bahwa faktor yang pertama terdiri dari 6 item yang berhubungan dengan focus pada pasar dan konsumen, dengan muatan faktor antara 0,53 0,85 . Oleh karena itu faktor 1 dinamakan dengan Pasar dan Konsumen. Faktor 3 terdiri dari tiga item yang berhubungan dengan analisis dan informasidengan muatan faktor $0,83-0,97$. Faktor dua dinamakan dengan faktor analisis dan informasi.

Faktor tiga memiliki tiga item yang mengandung pertanyaan tentang sumber daya, dengan muatan faktor $0,68-0,79$. Oleh karena itu faktor tiga dinamakan dengan faktor Sumber daya. Faktor empat memuat dua item pertanyaan yang berhubungan dengan analisis dan informasi, satu pertanyaan tentang perencanaan strategis dengan muatan faktor $0,51-0,76$. Oleh karena faktor 4 lebih menjelaskan tentang perencanaan strategis, maka faktor tersebut dinamakan dengan faktor perencanaan strategis.

Tabel 4 menunjukkan bahwa ke lima faktor yang didapatkan dari hasil analisis faktor, memiliki nilai Cronbach's alpha $>0,50$. Berdasarkan hasil dari uji validitas dan reliabilitas tersebut di atas, maka dapat disimpulkan bahwa instrumen yang digunakan adalah valid dan reliabel sehingga dapat digunakan lebih lanjut untuk penyebaran kuesioner dalam rangka mendapatkan data yang lebih lengkap untuk menjawab permasalahan yang telah disusun.

Tabel 5 menunjukkan bahwa analisis faktor untuk gaya kepemimpinan menghasilkan satu faktor dengan Cronbach alphanya sebesar 0,69. Sedangkan faktor untuk variabel intensitas persaingan yang terdiri dari tiga item yaitu, harga, kualitas produk dan teknologi produk juga dilakukan dan hanya menghasilkan satu variabel dengan nilai Cronbach alphanya 0,77. Berdasarkan hasil dari uji validitas dan reliabilitas untuk intensitas persaingan dan variabel gaya kepemimpinan, maka dapat disimpulkan bahwa instrumen yang digunakan adalah valid dan reliabel sehingga dapat digunakan lebih lanjut untuk menjawab permasalahan dalam penelitian ini. 
Tabel 4

Validitas Indikator Variabel Praktek Bisnis

\begin{tabular}{|c|c|c|c|c|}
\hline \multirow[b]{2}{*}{ Item Pertanyaan variabel independen } & \multicolumn{4}{|c|}{ Component } \\
\hline & 1 & 2 & 3 & 4 \\
\hline \multicolumn{5}{|l|}{ X1: Pasar \& Konsumen (PK) } \\
\hline Pasar \& Konsumen4 & 0,85 & & & \\
\hline Pasar \& Konsumen5 & 0,78 & & & \\
\hline Pasar \& Konsumen2 & 0,76 & & & \\
\hline Pasar \& Konsumen1 & 0,65 & & & \\
\hline Pasar \& Konsumen3 & 0,63 & & & \\
\hline Perencanaan Strategis1 & 0,53 & & & \\
\hline RELIABILITY & 0,83 & & & \\
\hline \multicolumn{5}{|l|}{ X2: Analisis dan Informasi } \\
\hline Analisis \& Informasi 3 & & 0,97 & & \\
\hline Analisis \& informasi 2 & & 0,86 & & \\
\hline Analisis \& informasi 1 & & 0,83 & & \\
\hline RELIABILITY & & 0,89 & & \\
\hline \multicolumn{5}{|l|}{ X3: Sumber Daya } \\
\hline Sumber daya 5 & & & 0,79 & \\
\hline Manajemen proses 2 & & & 0,70 & \\
\hline Sumber daya 1 & & & 0,68 & \\
\hline Reliability & & & 0,65 & \\
\hline \multicolumn{5}{|l|}{ X4: Perencanaan Strategis } \\
\hline Analisis \& Informasi4 & & & & 0,76 \\
\hline Perencanaan Strategis2 & & & & 0,64 \\
\hline Analisis \& Informasi5 & & & & 0,51 \\
\hline Reliability & & & & 0,59 \\
\hline Initial Eigenvalue & 4,60 & 3,29 & 1,86 & 1,62 \\
\hline Percentage of Variance Explained & 23,02 & 16,48 & 9,33 & 8,13 \\
\hline Cumulative Percentage of Variance Explained & 23,02 & 39,51 & 48,84 & 56,98 \\
\hline
\end{tabular}

Tabel 5

Validitas Indikator Variabel Gaya Kepemimpinan dan Praktek Bisnis

\begin{tabular}{lc}
\hline \multirow{2}{*}{ Item Pertanyaan: Gaya Kepemimpinan (X5) } & Component \\
\cline { 2 - 2 } Gp 1 & $\mathbf{1}$ \\
\hline Gp 9 & 0,80 \\
\hline Gp 10 & 0,73 \\
\hline Gp8 & 0,63 \\
\hline Reliability & 0,58 \\
\hline Initial Eigenvalue & $\mathbf{0 , 6 9}$ \\
Percentage of Variance Explained & $\mathbf{2 , 5 6}$ \\
Cumulative Percentage of Variance Explained & $\mathbf{5 9 , 6 8}$ \\
& $\mathbf{5 9 , 6 8}$ \\
\hline Item Pertanyaan:Intensitas Persaingan (X6) & \\
\hline Kualitas & \\
\hline Teknologi & 0,89 \\
\hline Harga & 0,83 \\
\hline Reliability & 0,75 \\
\hline Initial Eigenvalue & $\mathbf{0 , 7 7}$ \\
Percentage of Variance Explained & $\mathbf{2 , 0 6}$ \\
Cumulative Percentage of Variance Explained & $\mathbf{6 8 , 9 6}$ \\
\hline
\end{tabular}


Untuk menjawab permasalahan yang dikemukakan pada awal penelitian ini, maka jawaban penelitian tersebut diperoleh melalui analisis data dengan menggunakan regresi linear berganda. Hasil dari regresi linear berganda ditampilkan sebagaimana yang tertera pada table 6 di bawah ini.

Dari Table 6 dapat dijelaskan bahwa terdapat pengaruh positif antara gaya kepemimpinan, praktek bisnis dan intensitas persaingan terhadap kinerja UKM di propinsi Aceh yang dibuktikan oleh signifikansi $\mathrm{F}=0.021$. Besarnya pengaruh antara variabel gaya kepemimpinan, praktek bisnis dan intensitas persaingan dengan kinerja UKM adalah sebesar $12 \%$. Secara parsial, dapat dijelaskan bahwa variabel intensitas persaingan (X6) memiliki pengaruh yang negative dengan kinerja UKM ( $\beta$ $=-0.34, \quad \alpha=0.02$ ). Hal tersebut mengungkapkan bahwa semakin tinggi persaingan yang terjadi dapat menyebabkan penurunan kinerja keuangan UKM. Gaya kepemimpinan (X5), tidak memiliki pengaruh yang positif terhadap kinerja UKM di propinsi Aceh $(\beta=0.15 \alpha=0.13)$. Hasil ini menjelaskan bahwa kinerja UKM tidak dipengaruhi oleh gaya kepemimpinan yang dijalankan oleh pimpinan UKM. Hasil yang tidak signifikan ini dikarenakan bahwa pimpinan dalam menjalankan UKM di Indonesia khususnya di Propinsi Aceh, pengelolaannya lebih kepada pengeloaan secara kekeluargaan.Sehingga pemimpin tidak memberikan kontribusi yang cukup berarti bagi keberhasilan usaha. Untuk praktek bisnis, hanya perencanaan strategis (X4) yang memiliki pengaruh positif terhadap peningkatan kinerja UKM dengan $\beta=0.28, \quad \alpha=0.01$. Hasil statistik tersebut memberikan gambaran bahwa perencanaan usaha yang baik dan tersusun secara jelas dalam pengelolaan UKM dapat meningkatkan kinerja UKM itu sendiri.. Sedangkan untuk variabel praktek bisnis yang terdiri dari sumber daya $(\beta=-0.07, \alpha=0.53)$, analisis dan informasi $(\beta=-0.08, \alpha=0.39)$, serta pasar dan konsumen $(\beta=0.19, \alpha=0.14)$ tidak memiliki pengaruh signifikan terhadap peningkatan kinerja UKM di propinsi Aceh. Hasil yang tidak signifikan dalam penelitian ini untuk sumber daya, analisis dan informasi serta pasar dan konsumen dimungkinkan karena adanya keterbatasan yang dimiliki oleh UKM di propinsi Aceh, baik itu untuk sumber dayanya, analisis dan informasi serta kurangnya orientasi akan pasar dan kurangnya perhatian terhadap konsumen. Seperti lazimnya UKM di Indonesia, UKM di propinsi Aceh juga sangat jarang melakukan perencanaan yang baik untuk sumber daya manusianya. Usaha yang dijalankan hanya berdasarkan keahlian turun temurun yang dimiliki oleh pegawainya dengan sedikit sekali pelatihan yang diberikan. Demikian juga dengan analisis dan informasi, pemilik UKM juga jarang melakukan analisis terhadap informasi-informasi yang seharusnya mereka miliki berkaitan dengan usaha yang dijalankan, di tambah lagi dengan penguasaan teknologi yang minim. Hasil penelitian ini sejalan dengan apa yang diutarakan oleh Mitzer serta Musselman dan Hugehs (1994) tentang ciri-ciri umum usaha kecil yaitu; (1) kegiatan cenderung tidak formal dan jarang

Tabel 6

Analisis Regresi Linear Berganda

Pengaruh Gaya Kepemimpinan dan Praktek Bisnis terhadap Kinerja UKM di Propinsi Aceh

\begin{tabular}{lccc}
\hline \multicolumn{1}{c}{ Variabel } & Koefisien & $\mathbf{t}_{\text {hitung }}$ & Sig \\
\hline Constant & & 1.87 & 0.63 \\
Intensitas Persaingan (X6) & -0.34 & -2.23 & 0.02 \\
Perencanaan Strategis (X4) & 0.28 & 2.58 & 0.01 \\
Pasar dan Konsumen (X1) & 0.19 & 1.47 & 0.14 \\
Analisis dan Informasi (X2) & -0.08 & -0.84 & 0.39 \\
Sumber Daya (X3) & -0.07 & -0.62 & 0.53 \\
Gaya Kepemimpinan (X5) & 0.15 & 1.50 & 0.13 \\
\hline & & & \\
\hline $\mathrm{R}=0.35$ & $\mathrm{~F}$ hitung & & \\
$\mathrm{R}^{2}=0,12$ & Sign F = $=0.021$ & & \\
Adjusted $\left(R^{2}\right)=0,07$ & & & \\
\hline
\end{tabular}


yang memiliki rencana usaha, (2) Struktur organisasi bersifat sederhana, (3) Jumlah tenaga terbatas dengan pembagian kerja yang longgar, (4) Kebanyakan tidak melakukan pemisahan antara kekayaan pribadi dengan kekayaan perusahaan, (5) Sistem akuntansi kurang baik, bahkan kadangkadang tidak memilikinya sama sekali, (6) Skala ekonomi terlalu kecil sehingga sukar menekan biaya, (7) Kemampuan pemasaran serta diversifikasi pasar cenderung terbatas dan (8) Margin keuntungan sangat tipis.

\section{KESIMPULAN}

Dari hasil survey yang dilakukan dapat disimpulkan bahwa kondisi yang terdapat pada UKM di Propinsi Aceh masih memiliki dan menjalankan praktek bisnis yang sangat sederhana sehingga menyebabkan ketidakmampuan UKM yang ada untuk bersaing lebih baik, dari empat variabel dalam praktek bisnis yaitu perencanaan strategis, analisis dan informasi, pasar dan konsumen serta sumber daya, hanya perencanaan strategis yang memiliki pengaruh terhadap kinerja UKM di propinsi Aceh. Hal ini dapat dijelaskan bahwa, sudah menjadi karaterikstik UKM yang ada di Indonesia khususnya UKM di propinsi Aceh memiliki sumber daya yang minim, penggunaan informasi yang rendah serta kurang fokus pada pasar dan konsumen. Sehingga hanya perencaan yang baik dan jelas yang dapat memberikan kontribusi terhadap pengembangan usaha.

Dari kesimpulan yang dihasilkan, ada beberapa rekomendasi yang diajukan Pemerintah khususnya untuk Pemerintah Aceh untuk lebih memberikan pendampingan terhadap UKM yang ada karena usaha ini memberikan kontribusi yang besar terhadap perekonomian, untuk itu kendala dan masalah yang mereka hadapi sebaiknya ditindaklanjuti dengan cepat. Seperti untuk urusan pasar, sebaiknya akses para pengusaha kecil ini ke konsumen dapat dibina lebih baik lagi, sehingga mereka dapat mengetahui dengan baik apa saja yang dikehendaki oleh pasar dan konsumen. 


\section{REFERENSI}

Armandi, B., Oppedisano, J., Sherman, H. (2003). Leadership Theory and Practice: A Case in Point", Management Decision, Vol. 41, No. 10, pp. 1076-88.

Anoraga, P., Sudantoko, D., (2002). Koperasi, Kewirausahawan dan Usaha Kecil, Penerbit Reieneka Putra, Jakarta.

Chiara, A. D., and Atonio, M., (2002). Success Factors in SMEs' International Processes: An Italian Investigation, Journal of Small Business Management, 40(2), 141-153.

Claycomb, C., Drge, D., Germain, R., (1999). The effect of just-in-time with customers on organizational design and performance. International Journal of Logistic Mangement, 10(1), 37-58.

Drucker, P. F., (1985). Inovasi dan Kewiraswastaan, terjemahan Rusjdi Naif, Erlangga, Jakarta.

Ghozali, I., (2002). Aplikasi Multivariate dengan Program SPSS, Badan Penerbit Universitas Dipenogoro, Semarang.

Gosh, B.C., Tan, W. L., Tan T.M., Chan, Ben., (2001). The Key Success Factors, Distinctive Capabilities and Strategic Thrust of Top SMEs in Singapore, Journal of Business Research, 51 : 209-221.

Gray, J. H., (1999). A Predictive Model of Small Business Success, Academy of Entrepreneurship Journal. 5 (2): 25-36.

Hair, at al., (2006). Data Multivariate Analysis, edisi 6, Upper Saddle River: Printice Hall.

Hartman, S. J., Harri, O. J., (1992). Market Analysis in the business plan: Venture capitalist preception. Journal of Smal Business Management. 38-46.

Hendrics, K.B., Singhal, V.R., (1997). Does Implementing an Effective TQM Program Actually Improve Operating Performance? Impirical Evidence from Firm that Have Won Quality Awards. Management Science. 43.

Hisrich, R. D., Michael, P. P., (1998), Entrepeneurship, Fourth Edition, Mc Graw Hill, Boston.

Hult, G.T.M., Snow, C.C., Kandemir, C., (2003). The Role of Entrepreneurship in Building Cultural Competitiveness in Different Organizational Types, Journal of Management, 29 (3): 401-426.

Kohli, A. K., Jaorski, B.J., (1990) Market orientation: The Construct Research Propositions and Managerial Implication. Journal of Marketing, 54, 118.

Maholtra, N.K., (1996). Marketing Research : Analysis Applied Orientation, Second Edition, Prentice Hall International Inc., New Jersey.

Mosakowski, E., (1993). A resource based perspective on the dynamic strategy performance relationship: an empirical examination of the focus and differentiation strategies in entrepreneurial firms, Journal of Management, 19(4), 819-839. 
Meredith, G., G., (2002), Kewirausahawan : Teori dan Praktek, Terjemahan, Andre Asparsayogi, PPM, Jakarta.

Murphy, G. B., Trailer, J. W., Hill, R.C., (1996). Measuring Performance in Entrpreneurship Research. Journal of Business Research, 36, 15-23.

Nunnally, J. (1978). Psychometric Theory. New York, McGraw-Hill.

Sekaran, U., (1992). Research Methods for Business : A Sill Bulding Approach, John Wiley \& Sons, New York.

Singarimbun M., Efendi, S., (1995). Metode Penelitian Survey, Cetakan Kedua, LP3ES, Jakarta.

Suryana (2001). Kewirausahan, Salemba, Jakarta.

Tambunan, T. T. H(2002). Usaha Kecil dan Menengan di Indonesia, Beberap Isu Penting, Salemba Empat, Jakarta.

Umar, Husein (1999), Riset Strategi Perusahaan, PT. Gramedia Pustaka Utama, Jakarta.

Wheelen, T. L., James, D, H., (2002). Strategic Management and Business Policy, Eight Edition, Pearson Education, New Jersey.

Wisardja, I. W., (2000) Analisis Lingkungan Industri Kerajinan Ukiran Kayu di Kabupaten Gianyar, Provinsi Bali, Thesis, PPs Universitas Brawijaya Malang.

Zimmerer, T. W., Norman, M. S., (1998). Pengantar Kewirausahaan dan Manajemen Usaha Kecil, terjemahan, Yanto Sidik Pratiknyo dan Edina T. Tramidzi, PT. Prenhallindo, Jakarta. 
